\title{
EFEKTIVITAS MEDIA BOOKLET DAN LEAFLET TERHADAP PENGETAHUAN REMAJA PUTRI TENTANG DAMPAK KEHAMILAN REMAJA
}

\author{
${ }^{1}$ Lia Artika Sari \\ 1.2jurusan Kebidanan, Poltekkes Kemenkes Provinsi Jambi, \\ e-mail: $\underline{\text { lias39285@gmail.com }}$
}

\begin{abstract}
Abstrak
Kehamilan remaja adalah kehamilan yang terjadi pada wanita usia 14-19 tahun baik melalui proses pranikah atau nikah. Kehamilan remaja berdampak negatif pada kesehatan remaja dan bayinya, juga dapat berdampak sosial dan ekonomi. Di Indonesia masih banyak remaja yang belum mendapatkan pengetahuan yang komprehensif mengenai dampak kehamilan remaja. Pencegahan terjadinya kehamilan remaja dapat berupa pendidikan kesehatan kepada remaja dengan media Booklet dan Leaflet. Penelitian ini merupakan penelitian quasi eksperimen dengan rancangan two group pre-test post-test design. Sampel pada penelitian ini berjumlah 56 orang. Teknik pengambilan sampel dengan cara proporsional stratified random sampling. Analisa data yang digunakan dalam penelitian ini adalah analisa univariat untuk mengetahui pengaruh sebelum dan sesudah diberikan booklet dan leaflet dengan menggunakan Uji $T$ dependen, dan analisa bivariat untuk mengetahui efektivitas media booklet dan leaflet menggunakan Uji $T$ independen. Hasil penelitian menunjukkan bahwa booklet dan leaflet memiliki pengaruh dalam meningkatkan pengetahuan remaja tentang dampak kehamilan remaja dengan nilai $p$-value $0,001<0,05$. Dari hasil uji $T$ independen menunjukkan terdapat perbedaan efektivitas antara booklet dan leaflet dengan nilai p-value $0,001<0,05$. Booklet dan leaflet memiliki pengaruh dalam meningkatkan pengetahuan, jika dibandingkan kedua media tersebut media booklet lebih efektif dibandingkan media leaflet dalam meningkatkan pengetahuan remaja tentang dampak kehamilan remaja di SMA Swasta Pertiwi Kota Jambi.
\end{abstract}

Kata Kunci : Booklet; Leaflet; Pengetahuan

\begin{abstract}
Teenage pregnancy is a pregnancy that occurs in women aged 14-19 years either through premarital or marriage. Teenage pregnancy has a negative impact on the health of adolescents and their babies, can also have social and economic impacts. In Indonesia there are still many teenagers who have not received comprehensive knowledge about the effects of teenage pregnancy. Prevention of teenage pregnancy can be in the form of health education to adolescents with booklet and leaflet media. This research is a quasiexperimental study with a two-group design pre-test post-test design. The sample in this study amounted to 56 people. The sampling technique was proportional stratified random sampling. Data analysis used in this study is univariate analysis to determine the effect before and after being given booklets and leaflets using dependent $T$ test, and bivariate analysis to determine the effectiveness of media booklets and leaflets using independent $T$ test. The results showed that booklets and leaflets had an influence in increasing the knowledge of adolescents about the impact of teenage pregnancy with a p-value of $0.001<0.05$. From the results of the independent $T$ test shows there is a difference in effectiveness between booklets and leaflets with p-value of $0.001<0.05$. Booklets and leaflets had influence in improving knowledge, when compared to the two media booklets the effectiveness of leaflet media in promoting youth's enthusiasm about the impact of teenage pregnancy in Pertiwi Private Senior High School in Jambi City.
\end{abstract}

Keywords : Booklets; Leaflets; knowledge 


\section{PENDAHULUAN}

Menurut World Health Organization (WHO), remaja adalah penduduk dalam rentang usia 10 hingga 19 tahun. Menurut Peraturan Menteri Kesehatan RI nomor 25 tahun 2014, remaja adalah penduduk dalam rentang usia 10-18 tahun. Sementara itu, menurut Badan Kependudukan dan Keluarga Berencana Nasional (BKKBN), rentang usia remaja adalah 10-24 tahun dan belum menikah. Perbedaan definisi tersebut menunjukkan bahwa dak ada kesepakatan universal mengenai batasan kelompok usia remaja. Namun begitu, masa remaja itu diasosiasikan dengan masa transisi dari anak-anak menuju dewasa. Masa ini merupakan periode persiapan menuju masa dewasa yang akan melewati beberapa tahapan perkembangan penting dalam hidup. Selain kematangan fisik dan seksual, remaja juga mengalami tahapan menuju kemandirian sosial dan ekonomi, membangun identitas, akuisisi kemampuan (skill) untuk kehidupan masa dewasa serta kemampuan bernegosiasi/abstract reasoning (WHO, 2015).

Kehamilan remaja berdampak negatif pada kesehatan remaja dan bayinya, juga dapat berdampak sosial dan ekonomi. Kehamilan pada usia muda atau remaja antara lain beresiko kelahiran prematur, berat badan bayi lahir rendah (BBLR), perdarahan persalinan, yang dapat meningkatkan kematian ibu dan bayi. Kehamilan pada remaja juga terkait dengan kehamilan tidak dikehendaki dan aborsi tidak aman (Infodatin, 2016).

Menurut Badan Koordinasi Keluarga Berencana Nasional (BKKBN) tingginya usia kehamilan pada remaja Indonesia saat ini, bahkan menurut survei terakhir dari Badan Pusat Statistik (BPS) melalui Survei Demografi dan Kesehatan Indonesia (SDKI), tahun 2012 angka kehamilan remaja pada kelompok usia 15 - 19 tahun mencapai 48 dari 1.000 kehamilan (SDKI, 2012).

Hasil SDKI (2012), KRR menunjukkan bahwa pengetahuan remaja tentang kesehatan reproduksi belum memadai yang dapat dilihat dengan hanya $35,3 \%$ remaja perempuan dan $31,2 \%$ remaja laki-laki usia 15-19 tahun mengetahui bahwa perempuan dapat hamil dengan satu kali berhubungan seksual (SDKI, 2012).

Berdasarkan Riset Kesehatan Dasar (Riskesdas) 2013, yang mendata perempuan usia 10-54 tahun yang sedang hamil masih didapatkan kehamilan pada usia sangat muda ( $<15$ tahun), meskipun dengan proporsi yang sangat kecil $(0,02 \%)$, terutama di perdesaan $(0,03 \%)$. Sedangkan proporsi kehamilan pada usia 15-19 tahun adalah 1,97\% di perdesaan lebih tinggi dibanding perkotaan (Riskesdes, 2013).

Hasil penelitian Laboratorium Obstetri Ginekologi Universitas Gajahmada Yogyakarta ditemukan bahwa kehamilan remaja beresiko tinggi untuk terjadinya bayi lahir rendah (BBLR). Didapatkan adanya perbedaan yang bermakna $(p<0,01)$ antara frekuensi BBLR pada kelompok ibu usia remaja dan usia reproduksi sehat. Variabel yang bermakna terhadap resiko terjadinya BBLR adalah usia ibu, gizi dan usia kehamilan. Hasil penelitian menyimpulkan kehamilan pada usia remaja memberikan resiko terjadinya BBLR 4 kali lebih besar dibandingkan dengan kehamilan pada usia reproduksi sehat (BKKBN dan UNFPA, 2005 dalam Saroha Pinem, 2009:321).

Menurut Data Dinas Kesehatan Kota Jambi (2016), menunjukkan angka kehamilan pada remaja usia <18 tahun pada tahun 2016 berjumlah 107 remaja, diantaranya yang menduduki 5 besar adalah di Puskesmas Putri Ayu yaitu sebanyak 44 orang (41,12\%), Kebun Handil 27 orang $(25,23 \%)$, Payo Selincah dan Pal X 9 orang $(8,41 \%)$ dan Paal Merah II 6 orang $(5,60 \%)$.

Sedangkan angka kehamilan pada remaja usia $<18$ tahun pada tahun 2017 menurun yaitu berjumlah 77 remaja dibandingkan pada tahun 2016. Angka tertinggi yang menduduki 5 besar adalah di Puskesmas Putri Ayu yaitu sebanyak 21 orang (27,3\%), Paal Merah II 11 orang (14,3\%), Payo Selincah sebanyak 10 orang (13\%), Pal X sebanyak 8 orang (10,4\%), Pal V dan Kenali Besar sebanyak 5 orang $(6,5 \%)$. Dan angka yang tertinggi antara tahun 2016 
dan tahun 2017 masih di Puskesmas Putri Ayu (Dinkes Kota Jambi, 2017).

Kehamilan usia remaja memberikan gambaran bahwa perempuan tersebut baru memperoleh pendidikan 9 tahun, tamat SLTP atau putus sekolah SLTA hal ini akan mempengaruhi banyak hal seperti perawatan anak, pendidikan anak, pengembangan fisik serta mental anak dan juga kehidupan sosial keluarga secara keseluruhan (Soetjiningsih, 2007:139).

Masalah-masalah kesehatan reproduksi menunjukan minimnya pengetahuan tentang kesehatan reproduksi. Pendidikan mengenai kesehatan reproduksi merupakan salah satu solusi pencegahan terhadap terjadinya penyakit kesehatan reproduksi. Penyuluhan oleh lembaga kesehatan merupakan salah satu cara memberikan pendidikan kesehatan reproduksi. Penyuluhan lebih banyak dilaksanakan di tingkat Sekolah Menengah Atas (SMA) dari pada Sekolah Menengah Pertama (SMP).

Pada umumnya dalam proses pendidikan kesehatan ini tidak secara langsung disampaikan, melainkan menggunakan bantuan media. Media adalah alat bantu yang digunakan untuk memeragakan sesuatu dalam proses pendidikan atau pengajaran, sehingga sasaran dapat meningkatkan pengetahuannya yang akhirnya diharapkan dapat berubah perilakunya ke arah positif terhadap kesehatan (Notoatmodjo, 2010:290). Booklet adalah suatu media untuk menyampaikan pesan-pesan kesehatan dalam bentuk buku, baik berupa tulisan maupun gambar (Notoatmodjo, 2007:69). Leaflet adalah bentuk penyampaian informasi atau pesan kesehatan melalu lembaran yang dilipat. Isi informasi dapat dalam bentuk kalimat maupun gambar atau kombinasi (Notoatmodjo, 2007:70).

\section{METODE PENELITIAN}

Populasi dalam penelitian ini adalah seluruh siswi SMA Swasta Pertiwi Kota Jambi yang berjumlah 123 orang dengan jumlah sampel sebanyak 56 responden yang diambil menggunakan teknik proporsional stratified random sampling.

\section{HASIL DAN PEMBAHASAN}

Tabel 1.

Distribusifrekuensi pengetahuan responden tentang dampak kehamilan remaja sebelum diberikan booklet

\begin{tabular}{cccc}
\hline No & $\begin{array}{c}\text { Pengetahuan } \\
\text { sebelum } \\
\text { pemberian } \\
\text { media booklet }\end{array}$ & Jumlah & $\%$ \\
\hline 1 & Kurang baik & 24 & 85,7 \\
\hline 2 & Baik & 4 & 14,3 \\
\hline & Total & 28 & 100,0 \\
\hline
\end{tabular}

Sumber : data peimer

Tabel 2. Distribusi frekuensi pengetahuan responden tentang dampak kehamilan remaja sesudah diberikan media booklet

\begin{tabular}{cccc}
\hline No & $\begin{array}{c}\text { Pengetahuan } \\
\text { sesudah pemberian } \\
\text { media booklet }\end{array}$ & Jumlah & $\%$ \\
\hline 1 & Kurang baik & 4 & 7,1 \\
\hline 2 & Baik & 24 & 85,7 \\
\hline & Total & 28 & 100,0 \\
\hline
\end{tabular}

Sumber : data peimer

Tabel 3. Distribusi frekuensi pengetahuan responden tentang dampak kehamilan remaja sebelum pemberian media leaflet

\begin{tabular}{cccc}
\hline No & $\begin{array}{c}\text { Pengetahuan } \\
\text { sebelum } \\
\text { pemberian } \\
\text { media leaflet }\end{array}$ & Jumlah & $\%$ \\
\hline 1 & Kurang baik & 23 & 82,1 \\
\hline 2 & Baik & 5 & 17,9 \\
\hline & Total & 28 & 100,0
\end{tabular}

Sumber : data peimer

Tabel 4. Distribusi frekuensi pengetahuan responden tentang dampak kehamilan remaja sesudah diberikan media leaflet

\begin{tabular}{cccc}
\hline No & $\begin{array}{c}\text { Pengetahuan } \\
\text { sesudah } \\
\text { pemberian } \\
\text { media leaflet }\end{array}$ & Jumlah & $\%$ \\
\hline 1 & Kurang baik & 13 & 46,4 \\
\hline 2 & Baik & 15 & 53,6 \\
\hline & Total & 28 & 100,0 \\
\hline
\end{tabular}

Sumber : data peimer 
Tabel 5. Nilai rata-rata efektivitas antara media booklet dan media leaflet terhadap pengetahuan remaja putri tentang dampak kehamilan remaja di SMA Swasta Pertiwi Kota Jambi.

\begin{tabular}{ccccc}
\hline & $\begin{array}{c}\text { Kelompok } \\
\text { Eksperimen }\end{array}$ & N & Mean & Sig \\
\cline { 2 - 5 } Penget & Booklet & 28 & 8,07 & 0,00 \\
ahuan & & & & 1 \\
\cline { 2 - 5 } & Leaflet & 28 & 7,39 & \\
\cline { 2 - 5 } & Total & 56 & & \\
\hline
\end{tabular}

Sumber : data peimer

Dari tabel di atas menunjukkan hasil analisis data menggunakan uji T-test independen untuk menemukan perbedaan efektivitas penggunaan media booklet dan media leaflet terhadap peningkatan pengetahuan remaja tentang dampak kehamilan remaja. Berdasarkan analisis diperoleh nilai $\mathrm{p}$ $0,001<0,05$, yang berarti terdapat perbedaan yang signifikan nilai pengetahuan antara dua kelompok media booklet dan media leaflet. Sehingga nilai rata-rata (mean) yang di hasilkan media booklet lebih tinggi di bandingkan nilai rata-rata (mean) leaflet, yang menandakan media booklet lebih efektif dibandingkan media leaflet.

Berdasarkan hasil penelitian dapat diketahui pengetahuan dari 28 responden sebelum dan sesudah diberikan media booklet terjadi peningkatan sebesar $35,8 \%$. Hasil ini menunjukkan adanya pengaruh pemberian media booklet terhadap pengetahuan responden tentang dampak kehamilan remaja. Hal ini menunjukkan bahwa pemberian media booklet dapat meningkatkan pengetahuan responden tentang dampak kehamilan remaja dengan hasil penelitian dimana jumlah responden yang mempunyai pengetahuan baik mengalami peningkatan setelah diberikan booklet.

Pemberian media booklet bertujuan untuk memberikan informasi tentang suatu peristiwa atau kegiatan tertentu. Pemeberian media booket mempunyai kelebihan berupa buku kecil dapat dibawa kemana-mana sehingga dapat dibaca dimana saja untuk meningkatkan pengetahuan.

Hal ini sejalan dengan penelitian Malikatul Ma'munah (2015), tentang pengaruh pendidikan kesehatan dengan booklet terhadap pengetahuan nutrisi ibu laktasi diwilayah kerja puskesmas Ciputat Timur. Hasil uji Wilcoxon menunjukkan adanya peningkatan pengetahuan yang signifikan antara sebelum dan sesudah intevensi dengan $(\mathrm{p}=0.0005)$.

Hal ini sejalan dengan penelitian Surya Wibowo (2013), tentang pengaruh prommosi kesehatan metode audio visual dan metode buku saku terhadaap peningkatan pengetahuan penggunaan monosodium glutamat (MSG) pada ibu rumah tangga. Hasil analisis bivariat menunjukkan bahwa terdapat pengaruh promosi kesehatan degan metode buku saku terhhadap peningkatan pengetahuan tentang penggunaan MSG $(\mathrm{p}=0,00)$

Menurut Notoatmodjo (2010), seseorang yang terpapar informasi mengenai suatu topik tertentu akan memiliki pengetahuan yang lebih daripada yang tidak terpapar informasi, begitu juga informasi tentang dampak kehamilan remaja yang diberikan kepada responden melalui booklet diharapkan dapat meningkatkan pengetahuan responden.

Booklet memiliki kelebihan yaitu suatu media untuk menyampaikan pesan secara terperinci karena bisa lebih banyak mengulas tentang pesan yang disampaikannya, dengan begitu booklet dapat meningkatkan pengetahuan remaja tentang dampak kehamilan remaja.

3.1 Gambaran pengetahuan remaja tentang dampak kehamilan remaja sebelum dan sesudah diberikan media leaflet

Berdasarkan hasil penelitian dapat diketahui pengetahuan dari 28 responden sebelum dan sesudah diberikan media leaflet terjadi peningkatan sebesar $17,9 \%$. Hasil ini menunjukkan adanya pengaruh pemberian media leaflet terhadap penegtahuan responden tentang dampak kehamilan remaja. Bahwa pemberian media leaflet dapat meningkatkan pengetahuan responden tentang dampak 
kehamilan remaja dengan hasil penelitian dimana jumlah responden yang mempunyai pengetahuan baik mengalami peningkatan setelah diberikan leaflet.

Pemberian media leaflet bertujuan untuk memberikan informasi tentang suatu peristiwa atau kegiatan tertentu. Pemeberian media leaflet mempunyai kelebihan dapat disimpan lama, kalau lupa bisa dilihat kembali, dapat dipakai sebagai bahan bacaan rujukan.

Hasil penelitian ini sejalan dengan penelitian Dwi Ambar Sari (2016) tentang Pengaruh Pendidikan Kesehatan HIV/AIDS Melalui Metode Audiovisual Dan Leaflet Terhadap Tingkat Pengetahuan Dan Sikap Seks Pranikah Pada Remaja Di SMA XX Semarang. Hasil uji statistik didapatkan p-valuesebesar 0.000 yang artinya pendidikan kesehatan melalui metode leaflet berpengaruh terhadap pengetahuan seks bebas pranikah pada remaja.

Pemberian informasi secara formal maupun tidak formal dapat meningkatkan pengetahuan. Pengetahuan diperoleh dari hasil belajar dengan dukungan media dalam pembelajaran tersebut. Leaflet merupakan salah satu media yang menunjang proses belajar untuk memperoleh pengetahuan tentang dampak kehamilan remaja. Media leaflet yang digunakan berisikan informasi dan gambar yang sesuai dengan pengetahuan tentang dampak kehamilan remaja, sehingga dengan adanya leaflet dapat meningkatkan pengetahuan remaja tentang dampak kehamilan remaja.

3.2 Efektivitas antara media booklet dan leaflet terhadap pengetahuan remaja putri tentang dampak kehamilan remaja

Hasil analisis perbedaan efektivitas antara media booklet dan media leaflet dalam meningkatkan pengetahuan remaja putri tentang dampak kehamilan remaja dengan menggunakan uji T-test independen dengan $p$ Value 0,001 <0,05 maka kesimpulan yang dapat diambil yaitu terdapat perbedaan efektivitas antara media booklet dan leaflet dalam meningkatkan pengetahuan remaja putri tentang dampak kehamilan remaja di SMA Swasta Pertiwi Kota Jambi. Selisih nilai ratarata responden sesudah diberikan media booklet dan leaflet sebesar 0,68 dengan nilai rata-rata booklet 8,07 dan nilai rata-rata leaflet 7,39.

Hasil penelitian ini menunjukkan bahwa booklet lebih efektif dibandikan leaflet terhadap pengetahuan remaja putri tentang dampak kehamilan remaja. Dengan demikian hipotesis pada penelitian ini adalah Ada pengaruh pemberian media booklet terhadap pengetahuan remaja putri tentang dampak kehamilan remaja di SMA Swasta Pertiwi Kota Jambi tahun 2018. Ada pengaruh pemberian media leaflet terhadap pengetahuan remaja putri tentang dampak kehamilan remaja di SMA Swasta Pertiwi Kota Jambi tahun 2018. Booklet lebih efektif dibandingkan leaflet dalam peningkatan pengetahuan remaja putri tentang dampak kehamilan remaja di SMA Swasta Pertiwi Kota Jambi tahun 2018.

Hal ini sejalan dengan penelitian I Wawan Sutama Punia (2008), tentang membandingkan efektivitas bookle dengan leaflet dan upaya perbaikannya dalam meningkatkan pengetahuan dan sikap terhadap pencegahan HIV/AIDS dengan hasil uji $t$ dua sampel tidak berpasangan $\mathrm{p}(0.000<0,05)$ yang artinya booklet lebih efektif dibandingkan leaflet dalam meningkatkan pengetahuan siswa tentang pencegahan HIV/AIDS.

Hal ini sejalan dengan penelitian Diah Ratna fitriastutik (2010), tentang efektivitasn booklet dan permainan tebak gambar dalam meningkatkan pengetahuan dan sikap kelas IV terhadap karies gigi di SD Negri 01,02, dan 03 Bandengan kecamatan jepara kabupaten jepara tahun ajaran 2009/2010. Hasil uji statistik disimpulkan bahwa booklet lebih efektif daripada permainan tebak gambar dalam meningkatkan pengetahuan $(\mathrm{p}=0,004)$.

Alat bantu atau alat peraga sangat membantu sasaran didik dalam menerima informasi berdasarkan kemampuan penangkapan pancaindra. Semakin banyak indra yang digunakan semakin baik penerimaan sasaran didik terhadap pesan atau materi pendidikan kesehatan. Booklet merupakan salah satu alat peraga atau media untuk menyampaikan pesan-pesan kesehatan dalam bentuk buku, baik berupa tulisan maupun 
gambar. Setelah diberikan media booklet, terbukti bahwa kelompok eksperimen dengan media booklet memiliki peningkatan pengetahuan terhadap dampak kehamilan remaja yang lebih bermakna dibandingkan kelompok eksperimen dengan leaflet.

Menurut Notoatmodjo 2007, booklet merupakan suatu media untuk menyampaikan pesan-pesan kesehatan dalam bentuk buku, baik berupa tulisan maupun gambar yang proses penyampaiannya juga bisa disesuaikan dengan kondisi yang ada, lebih terperinci dan jelas, karena lebih banyak bisa mengulas tentang pesan yang disampaikannya.

\section{KESIMPULAN}

Berdasarkan hasil penelitian dan pembahasan tentang Efektivitas Media Booklet Dan Leaflet Terhadap Pengetahuan Remaja Putri Tentang Dampak Kehamilan Remaja Di SMA Swasta Pertiwi Kota Jambi disimpulkan bahwa:

1. Sebagian besar responden memiliki pengetahuan kurang baik tentang dampak kehamilan remaja sebelum diberikan media booklet di SMA Swasta Pertiwi Kota Jambi Tahun 2018.

2. Sebagian besar responden memiliki pengetahuan baik tentang dampak kehamilan remaja sesudah diberikan media booklet di SMA Swasta Pertiwi Kota Jambi Tahun 2018.

3. Sebagian besar responden memiliki pengetahuan kurang baik tentang dampak kehamilan remaja sebelum diberikan media leaflet di SMA Swasta Pertiwi Kota Jambi Tahun 2018.

4. Sebagian besar responden memiliki pengetahuan baik tentang dampak kehamilan remaja sesudah diberikan media leaflet di SMA Swasta Pertiwi Kota Jambi Tahun 2018.

5. Booklet memiliki keefektifan dalam meningkatkan pengetahuan tentang dampak kehamilan remaja dibandingkan Leaflet di SMA Swasta Pertiwi Kota Jambi Tahun 2018.

\section{UCAPAN TERIMA KASIH}

Puji syukur penulis panjatkan kehadirat Allah SWT karena atas limpahan rahmat dan karunia-Nya sehingga penelitian ini dapat terselesaikan. Tak lupa pula penulis mengucapkan terima kasih kepada semua pihak yang telah memberikan dukungan baik berupa tenaga pikiran mapun materi.

\section{DAFTAR PUSTAKA}

[1] Dewi. Wawan. 2010. Teori \& Pengukuran Pengetahuan, Sikap, dan Perilaku Manusia. Yogyakarta: Nuha Medika.

[2] Dinas Kesehatan Kota Jambi. 2016. Profil Kesehatan Kota Jambi. Jambi: Dinas Kesehatan Kota Jambi

[3] Dinas Kesehatan Kota Jambi. 2017. Profil Kesehatan Kota Jambi. Jambi: Dinas Kesehatan Kota Jambi

[4] Hasdianah. Sandu. 2013. Buku Ajar Kesehatan Reproduksi. Yogyakarta: Nuha Medika

[5] Hidayat. A. A. 2010. Metode Penelitian Kebidanan Teknik Analisis Data. Jakarta: Salemba Medika

[6] Hidayat. A. A. 2011. Metode Penelitian Keperawatan dan Teknik Analisis Data. Jakarta: Salemba Medika.

[7] Iqbal dkk. 2007. Promosi Kesehatan: Sebuah Pengantar Proses Belajar Mengajar dalam Pendidikan. Yogyakarta: Graha Ilmu

[8] Maryam. 2014. Promosi Kesehatan dalam Pelayanan Kebidanan. EGC: Jakarta

[9] Notoatmodjo. 2007. Promosi Kesehatan dan Ilmu Perilaku. Jakarta: PT. Rineka Cipta.

[10] Notoatmodjo. 2010. Metodologi Penelitian Kesehatan. Jakarta: PT. Rineka Cipta.

[11] Pinem, Saroha. 2009. Kesehatan Reproduksi \& Kontrasepsi. Jakarta: CV. Trans Info Media

[12] Manuaba, Ida Bagus. 1998. Ilmu Kebidanan Penyakit Kandungan Keluarga Berencana. Jakarta: EGC 
[13] Saryono. Ari Setiawan. 2011. Metodologi Penelitian Kebidanan DIII, DIV, S1 dan S2. Cet. ke-3, Oktober. Yogyakarta: Nuha Medika.

[14] Soetjiningsih. 2007. Buku Ajar Tumbuh Kembang Remaja dan Permasalahannya. Jakarta : Sagung Seto.

[15] Sugiyono, 2013. Metodelogi Penelitian Kuantitatif, Kualitatif Dan $R \& D$. Bandung: ALFABETA

[16] Syafrudin, Hamidah. 2009. Kebidanan Komunitas. Jakarta: EGC

[17] Diah Ratna fitriastutik. 2010. Efektivitas Booklet Dan Permainan Tebak Gambar Dalam Meningkatkan Pengetahuan Dan Sikap Kelas IV Terhadap Karies Gigi Di SD Negri 01,02, Dan 03 Bandengan Kecamatan Jepara Kabupaten Jepara Tahun Ajaran 2009/2010.

[18] Dwi Ambar Sari. 2016. Pengaruh Pendidikan Kesehatan HIV/AIDS
Melalui Metode Audiovisual dan Leaflet Terhadap Tingkat Pengetahuan dan Sikap Seks Bebas Pranikah pada Remaja di SMA XX Semarang.

[19] I Wawan Sutama. 2008. Membandingkan Efektivitas booklet dengan leaflet dan upaya perbaikannya dalam meningkatkan pengetahuan dan sikap terhadap pencgahan HIV/AIDS.

[20] Malikatul Ma'munah. 2015. Pengaruh Pendidikan Kesehatan Dengan Booklet Terhadap Pengetahuan Nutrisi Ibu Laktasi Di Wilayah Kerja Puskesmas Ciputat Timur.

[21] Surya Wibowo, Dyah Suryani. 2013. Pengaruh Promosi Kesehatan Metode Audio Visual Dan Metode Buku Saku Terhadap Peningkatan Pengetahuan Penggunaan Monosodium Glutamat (Msg) Pada Ibu Rumah Tangga. 